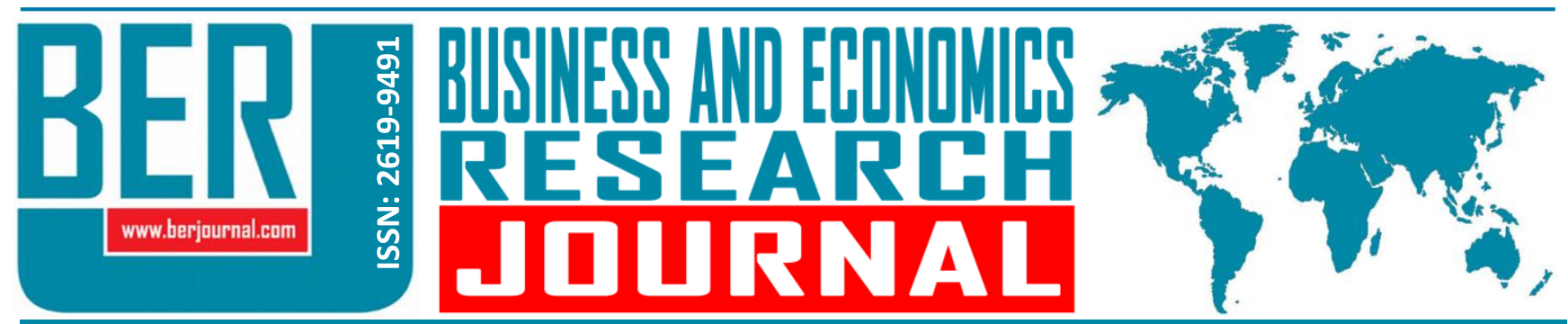

Business and Economics Research Journal Vol. 11, No. 4, 2020, pp. 925-938 doi: 10.20409/berj.2020.290

\title{
An Eye Toward the Future: Examining the Relationship Between Future Time Perspective and College Student Employment in the United States
}

\section{Christopher Manner ${ }^{\mathrm{a}}$}

\begin{abstract}
The purpose of this study is to examine the influence of future time perspective (FTP) on college student employment. The research data were collected using an online survey that was distributed to randomly selected participants at a university in the southeastern United States. A total of 219 undergraduate students participated in the study. Logistic regression analysis revealed that FTP exerts a significant influence on whether a student works while in college. Students higher in FTP were more likely to be employed. In addition, gender was found to moderate the relationship between FTP and college student employment, with the relationship being stronger for males than for females. The present research not only contributes to our understanding of college student employment, but it also has important implications for leaders in higher education. Faculty and administrators should recognize and appreciate that working college students are not only earning income to meet short term financial needs, but they also perceive employment as a means of improving their long-term future earnings. Internship and work-study coordinators could identify and target future-oriented students when recruiting quality candidates. To the extent that FTP is malleable, colleges and universities might consider prompting a greater orientation toward the future in those students who are not so inclined in order to spark greater interest in work-related programs.
\end{abstract}

Keywords: College Student Employment, Future Time Perspective, Logistic Regression, Gender

JEL: I20, J22, J24

\section{Introduction}

Many students work full or part time to help pay tuition, fees, and other costs of attending college. According to a study by HSBC Holdings (2018), 85\% of American university students rely on extra-curricular jobs to cover their costs, and for the majority (57\%) this is out of enhance their future employability. In the United States, 37\% of students work to gain experience that will help them get a job after graduation (HSBC Holdings, 2018). Working during college can help students acquire valuable skills and qualities employers look for when hiring recent college graduates. A study conducted on behalf of the Association of American Colleges and Universities, found that $60 \%$ of employers "think that having both field-specific knowledge and skills and a broad range of skills and knowledge that apply to a variety of fields is important for recent college graduates to achieve long-term career success at their company" (Hart Research Associates, 2016: 2). Employers expect new college graduates to have critical thinking, teamwork, communication, and leadership

a Assoc. Prof., PhD., Union University, McAfee School of Business, Program of Economics, Jackson, Tennessee, USA, cmanner@uu.edu (ORCID ID: 0000-0002-8386-2671) 
skills. By helping develop these skills, work experiences can help college students prepare for future professional success (Mitola, Rinto, \& Pattni, 2018).

Student employment is an important source of both financial support and student development. However, most studies of college student employment focus on the financial determinants of student work. Researchers have linked parental transfers, financial aid/student grants, tuition and fees, and credit constraints to the labor supply of college students (Kalenkoski \& Pabilonia, 2010; Bachmann \& Boes, 2014; Avdic \& Gartell, 2015; Neill, 2015; Broton, Goldrick-Rab, \& Benson, 2016). Few studies pay attention to the individual characteristics of working students. One trait that might impact a student's decision to work is future time perspective (FTP). According to Zimbardo and Boyd (1999), FTP can influence a wide range of feelings, thoughts, and behaviors. Because labor market participation is a planned activity that involves weighing costs and benefits at different points in time, students who focus more often on the future may be more likely to work while in college. The purpose of this study is to examine the influence of FTP on the likelihood of working during college. In addition, the moderating role of gender is considered.

\section{Literature Review}

\subsection{College Student Employment in the United States of America}

Today's undergraduates are more likely to work and work more hours per week than previous generations. In 1960, 25\% of full-time students ages 16 to 24 in the United States of America (USA) worked while enrolled in college compared to 41\% in 2017 (Snyder, de Brey, \& Dillow, 2019). Employment of fulltime, traditional college students began to grow in the mid-1960s and reached its peak at $52 \%$ in 2000 (Stern \& Nakata, 1991; Snyder et al., 2019). Approximately $60 \%$ of students who worked and attended college in the USA prior to COVID-19 reported their work hours were reduced or they lost their job during the pandemic (Garcia, Bohlig, \& Adkins, 2020). Almost all of the growth in student employment in the USA was the result of growth in students working extensively (i.e., 20 or more hours per week). The proportion of full-time, traditional college students working extensively has grown from 14\% in 1970 to 25\% in 2017 (Snyder et al., 2019).

In the USA, among full-time, traditional, undergraduate students in $2017,42.3 \%$ of women worked, compared to $36.1 \%$ of men. Racial differences indicate that employment was lower among Black students (36.7\%) than among students who were Hispanic (37.6\%) and White (42.5\%). The percentage of full-time, traditional undergraduates in the USA who were employed was higher at community colleges (44.5\%) than at 4-year colleges (37.8\%). A lower percentage of students attending private colleges (32\%) work compared to their peers at 4-year public institutions (39.4\%) (Snyder et al., 2019).

Financial issues play an important role in American students' decision to work, particularly for students from low-income families (Dundes \& Marx, 2006; Bound, Lovenheim, \& Turner, 2012). According to Scott-Clayton (2012), working students in the bottom income quartile are 28 percentage points more likely to say they could not afford school without working than those in the top quartile. Also, students from lowincome families are more likely to work extensively than those from high income families (Walpole, 2003). In addition to parental income, the costs of attending college also affects students' decision to work. The net price of schooling (tuition and fees less grants, waivers, fellowships and scholarships) has a positive effect on student work hours, particularly for 2-year college students (Kalenkoski \& Pabilonia, 2010).

Although many students work for financial reasons, some may see employment as a way to explore potentially satisfying occupations and gain real-world experiences and applications. The research results of Hobbs et al. (2007) suggest that most college students believe that relevant work experience will help them a great deal to prepare for their career after graduation. In fact, some studies do report a link between college student employment and higher future earnings (Stephenson, 1982; San, 1986; Douglas \& Attewell, 2018). Douglas and Attewell (2018) identify four mechanisms through which college employment might affect future earnings. First, employment during college experiences may help develop marketable skills that result in higher earnings after college. Second, working during college may serve as a signal of a job applicant's 
promise. Studies have shown that employers place more weight on internships and employment during school rather than academic credentials (e.g., grade point average and college major) when evaluating recent college graduates for employment (Fischer, 2014). Third, students who work during college may build social networks that are advantageous for gaining jobs after graduation. Finally, the correlation between college employment and post-college earnings may be spurious. That is, certain personality traits such as ambition, perseverance, or grit (Duckworth, 2018) may predispose students to seek employment opportunities to while attending college and also lead to better jobs and higher wages after college.

\subsection{Future Time Perspective}

Psychologists conceptualize FTP as the degree to which individuals are oriented toward the future, rather than the past or present (Zimbardo \& Boyd, 1999). Researchers have linked FTP to a variety of lifetime social and economic behaviors. For instance, some studies have documented that FTP is significantly correlated with occupational choice (Burks, Carpenter, Goette, \& Rustichini, 2009), credit card borrowing (Meier \& Sprenger, 2010), substance use and nutrition (Chabris et al., 2008), risky driving (Zimbardo, Keough, \& Boyd, 1997), tobacco, alcohol and illegal drug use (Keough, Zimbardo, \& Boyd, 1999) and risky health behaviors (Henson, Carey, Carey, \& Maisto, 2006). Sutter, Kocher, Glätzle-Rützler, and Trautmann (2013) found evidence that FTP among children aged 10 to 18 correlated with their Body Mass Index, savings behavior, and spending on alcohol and tobacco. Studies have also discovered a link between FTP and educational attainment, employment in young adulthood, performance in secondary school, unemployment, welfare participation, early death, obesity, and teenage childbearing (Golsteyn, Grönqvist, \& Lindahl, 2014; Cadena \& Keys, 2015).

Several studies have focused on the relationship between the FTP of young people and career identity development. FTP has been found to be an important determinant of career maturity (Savickas, Silling, \& Schwartz, 1984; Lennings, 1994), career decidedness (Ferrari, Nota, \& Soresi, 2010), and career planning (Marko \& Savickas, 1998; Janeiro, 2010). In a sample of adults seeking career counselling, Taber (2013) showed that FTP was related to motivation to engage in the career decision-making process and less indecision. Laghi, Baiocco, Liga, Guarino, and Baumgartner (2013) argued that those who achieve identity in the career life domain were more oriented towards the future. Using data from a longitudinal study of young people in Australia, Laughland-Booÿ, Newcombe, and Skrbiš (2017) found that individuals high in FTP were more ambitious and showed greater autonomous control over their career choice.

\subsection{FTP and College Student Employment}

There are several reasons to believe that students with a greater orientation toward the future might be more likely to work during college. First, employment is planned behavior. Students must decide whether to work, what type of work, where to work, and when to work. All of these planning decisions involve thoughts about the future. Student who are more future oriented might be more likely to make plans (Zimbardo \& Boyd, 1999), including plans to work. Second, for students to believe that employment has value (gaining skills, knowledge, and experience), they must recognize that change can take place over time. This also involves thoughts of the future. Third, working as a college student is an intertemporal choice. It involves consideration of costs and benefits, many of which occur in the future (Frederick, Loewenstein, \& O'donoghue, 2014). The experiential learning associated with employment is not immediate. In order for students to realize the positive effects of employment, they must persist over time. This ability to delay gratification is often linked to FTP (Zimbardo \& Boyd, 2008). Fourth, in a study of young adults undertaking their first years of university education, Taber and Blankemeyer (2015) suggest that students who focused more on the future rather than negative past experiences had less difficulty engaging in career exploration. Finally, working while enrolled in college is risky. Carnevale and Smith (2018) found that students who worked had lower grades and were more likely to drop out. The risk was especially high for low-income students. Plus, there is no guarantee the experiential learning from employment will have a significant future payoff. Numerous studies have confirmed that FTP is linked to the propensity to take risks (Zimbardo et al., 1997; Keough et al., 1999; Henson et al., 2006; Sékscińska, Rudzinska-Wojciechowska, \& Maison, 2018). These 
findings imply a positive relationship between FTP and college student employment. Hence, the following hypothesis is postulated:

H1. FTP will be positively related to the likelihood of working while in college.

\subsection{FTP and Gender}

Research examining gender differences and FTP indicate that the future orientation of men and women differ in ways that reflect the nature of sex role stereotypes and the roles and possibilities defined for them by their culture (Kite, Deaux, \& Haines, 2008). Women have greater diversity in their thoughts of the future than men, but men have fewer goals more evenly dispersed throughout their planning horizon (Greene \& DeBacker, 2004). That is, women imagine their future in terms of combinations of family, higher education, career, and leisure activities, whereas males focus primarily on employment and financial security. Research on FTP also reveals that males report more hopes and fears into the future in the career domain, whereas females report more socially oriented hopes and fears (Greene \& DeBacker, 2004). Given the prior research, the following hypothesis is proposed:

H2. Gender will moderate the positive relationship between FTP and college student employment, such that the relationship will be stronger for males than for females.

\section{Method}

\subsection{Participants}

An online (Qualtrics) survey was emailed to approximately 400 full-time students from the total population of undergraduates registered at 4-year university in a southeastern state of the United States. The survey was distributed to randomly selected participants using the university's listserv system. The 10minute survey contained items pertaining to personal characteristics, demographics, work and schoolrelated behaviors, parental information, and a scale for measuring FTP. The 235 students who participated in spring 2018 represent a response rate of $59 \%$. Of these, only 16 students (6.8\%) were eliminated due to missing data. Thus, the final sample included 219 participants. All participants were assured of confidentiality before and after taking the survey. The survey was approved by the university's institutional review board.

The sample consisted of $57 \%$ female and $43 \%$ male, ranging in age from 18 to 28 , with an average age of 20.17. Most participants were Caucasian (77\%), followed by African American (14\%), Asian (4\%), and Hispanic (3\%). Over half (51\%) of the respondents reported family income of more than $\$ 70,000$ per year, and $52 \%$ reported having a high school GPA greater than 3.75 . In terms of employment, $42 \%$ of the respondents reported working at the time of the survey. Of those students who were working, $83 \%$ reported working 20 hours or less. Table 1 describes the sample in detail.

Table 1. Demographic Characteristics of Participants

\begin{tabular}{lcc}
\hline & $n$ & $\%$ \\
\hline $\begin{array}{l}\text { Gender } \\
\text { Female } \\
\quad \text { Male }\end{array}$ & 125 & 57 \\
Age & 94 & 43 \\
18 & & \\
19 & 35 & 16 \\
20 & 59 & 27 \\
21 & 40 & 18 \\
$22+$ & 50 & 23 \\
Race & 35 & 16 \\
White/Caucasian & & \\
African American & 168 & 77 \\
& 31 & 14 \\
\hline
\end{tabular}


Table 1. Demographic Characteristics of Participants (Continued)

\begin{tabular}{|c|c|c|}
\hline \multicolumn{3}{|l|}{ Race } \\
\hline Hispanic & 7 & 3 \\
\hline Asian & 9 & 4 \\
\hline Native American & 2 & 1 \\
\hline Other & 2 & 1 \\
\hline \multicolumn{3}{|l|}{ Parent's Income } \\
\hline Under $\$ 20,000$ & 16 & 7 \\
\hline$\$ 20,000-\$ 29,999$ & 16 & 7 \\
\hline$\$ 30,000-\$ 39,999$ & 9 & 4 \\
\hline$\$ 40,000-\$ 49,999$ & 24 & 11 \\
\hline$\$ 50,000-\$ 59,000$ & 16 & 7 \\
\hline$\$ 60,000-\$ 69,000$ & 17 & 8 \\
\hline$\$ 70,000-\$ 79,999$ & 11 & 5 \\
\hline$\$ 80,000-\$ 89,999$ & 15 & 7 \\
\hline$\$ 90,000-\$ 99,999$ & 13 & 6 \\
\hline$\$ 100,000-\$ 109,000$ & 28 & 13 \\
\hline$\$ 110,000-\$ 119,000$ & 4 & 2 \\
\hline$\$ 120,000-\$ 129,000$ & 11 & 5 \\
\hline$\$ 130,000-\$ 139,000$ & 9 & 4 \\
\hline$\$ 140,000-\$ 149,000$ & 4 & 2 \\
\hline$\$ 150,000+$ & 26 & 12 \\
\hline \multicolumn{3}{|l|}{ High School GPA } \\
\hline Less than 2.50 & 2 & 1 \\
\hline $2.51-2.75$ & 7 & 3 \\
\hline $2.76-3.00$ & 11 & 5 \\
\hline $3.01-3.25$ & 13 & 6 \\
\hline $3.26-3.50$ & 24 & 11 \\
\hline $3.51-3.75$ & 48 & 22 \\
\hline $3.76+$ & 114 & 52 \\
\hline \multicolumn{3}{|l|}{ Employment } \\
\hline Not working & 127 & 58 \\
\hline Work 1-20 hours per week & 76 & 35 \\
\hline Work $21+$ hours per week & 16 & 7 \\
\hline
\end{tabular}

\subsection{Measurements}

The measure of undergraduate employment is based on student self-reports to survey questions. Students were first asked if they currently work. This information was used to create the dichotomous outcome employed ( 0 = student is not working; 1 = student is working).

The analysis includes various socio-demographic variables as both controls and important predictors. These variables include gender $(0=$ female; $1=$ male), age (in years), race $(0=$ whites; $1=$ all other $)$, parent's income, and high school GPA. (See Table A1 in the appendix section for a complete description of variable coding.)

FTP was measured using a four-item scale designed to assess the extent to which individuals focus on and plan for the future (Hershey \& Mowen, 2000). Although this scale has been used primarily in the financial planning and retirement literature, it has been described as a domain-general measure of FTP (Jacobs-Lawson, Hershey, \& Neukam, 2005). A sample item from the FTP instrument is "I enjoy thinking about how I will live $10+$ years in the future." All four statements use a 7-point Likert-type response format $(1=$ never like me, 7 = always like me). In the present study, the coefficient alpha level for this scale was found to be 0.71 . 


\section{Results}

\subsection{Preliminaries}

Before analysis, all variables were checked for normality, skewness, and kurtosis. A square root transformation (with appropriate reflection) was used to reduce skewness in the age and high school GPA variables. (See Table A2 in the appendix section for skewness and kurtosis statistics before and after transformations.) According to Aiken and West (1991), mean centering predictors helps to reduce the problems associated with multicollinearity that occur when examining interactions between variables. As such, the FTP scale's overall mean was subtracted from individuals' scale scores before conducting the analysis.

Table 2 reports the correlation matrix for the variables used in the analysis. Among the explanatory variables, there are no significantly high correlations; therefore, the possibility of multicollinearity is low. Using ordinary least square regression on the same specification as in Table 2, the analysis of variance inflation factor revealed that the model is free of multicollinearity (See Table A3 in the appendix section for variance inflation factor and Durbin-Watson statistics).

Table 2. Correlation Matrix of All Variables in the Analyses

\begin{tabular}{lllllll}
\hline & 1 & 2 & 3 & 4 & 5 & 6 \\
\hline 1) Employed & 1.00 & & & & & \\
2) Gender & -0.03 & 1.00 & & & & \\
3) Age & $0.24^{* *}$ & $-0.15^{*}$ & 1.00 & & & \\
4) Race & 0.04 & -0.10 & $0.25^{* *}$ & 1.00 & & \\
5) Parent's income & $-0.18^{*}$ & -0.01 & -0.10 & $-0.35^{* *}$ & 1.00 & \\
6) High School GPA & 0.05 & $-0.22^{* *}$ & $-0.18^{* *}$ & $-0.23^{* *}$ & $0.23^{* *}$ & 1.00 \\
7) FTP & $0.23^{* *}$ & $-0.14^{*}$ & 0.08 & 0.10 & 0.05 & $0.20^{* *}$ \\
\hline
\end{tabular}

Note: ${ }^{* *} p<0.01 ;{ }^{*} p<0.05$

\subsection{Logistic Regression}

Table 3 reports the results of three logistic regression models predicting college student employment. Model 1 reports the logistic regression with only the control variables entered - gender, age, parent's income, and high school GPA. Model 2 tests the direct effect of FTP $\left(\mathrm{H}_{1}\right)$ and Model 3 tests the interaction term between FTP and gender $\left(\mathrm{H}_{2}\right)$. All models report unstandardized beta coefficients and odds ratios.

Significant predictors of student employment are age, and parent's income, and FTP. According to model 1, the log odds of working during college is positively related to age. In other words, the older the student, the more likely it is they will be employed. The effect of parent's income has the expected sign: higher parental income decreases the likelihood that a student works during college. Together these variables explain a sizable portion of the variance in the dependent variable (Nagelkerke $R^{2}=0.133$ ). 
Table 3. Results of Hierarchical Logistic Regression Analysis

\begin{tabular}{lcccccc}
\hline & \multicolumn{2}{c}{ Model 1 } & \multicolumn{2}{c}{ Model 2 } & \multicolumn{2}{c}{ Model 3 } \\
\hline Predictor & $\beta$ & Odds Ratio & $\beta$ & Odds Ratio & B & Odds Ratio \\
Constant & $-13.64^{*}$ & - & $-13.19^{*}$ & - & $-15.51^{*}$ & - \\
Gender (0 = female, 1 = male) & -0.04 & 0.96 & 0.08 & 1.78 & 0.01 & 1.01 \\
Age & $3.04^{*}$ & 20.95 & $3.02^{*}$ & 20.39 & $3.54^{*}$ & 34.62 \\
Race (0 = white, 1 = all other) & -0.49 & 0.62 & -0.81 & 0.44 & -0.94 & 0.39 \\
Parent's Income & $-0.11^{*}$ & 0.90 & $-0.12^{*}$ & 0.89 & $-0.12^{*}$ & 0.89 \\
High School GPA & 0.34 & 1.41 & 0.22 & 1.24 & 0.23 & 1.25 \\
FTP & & & $0.18^{*}$ & 1.20 & 0.03 & 1.03 \\
FTP $\times$ Gender & & & & $0.33^{*}$ & 1.40 \\
\hline Chi-square & & & & & $38.16, \mathrm{df}=7, \mathrm{p}<0.0001$ \\
Nagelkerke R-square & $20.07, \mathrm{df}=5, \mathrm{p}<0.001$ & $30.31, \mathrm{df}=6, \mathrm{p}<0.0001$ & 0.242 &
\end{tabular}

Note: $\mathrm{N}=219 ;{ }^{*} p<0.01$

Figure 1. The Moderating Effect of Gender

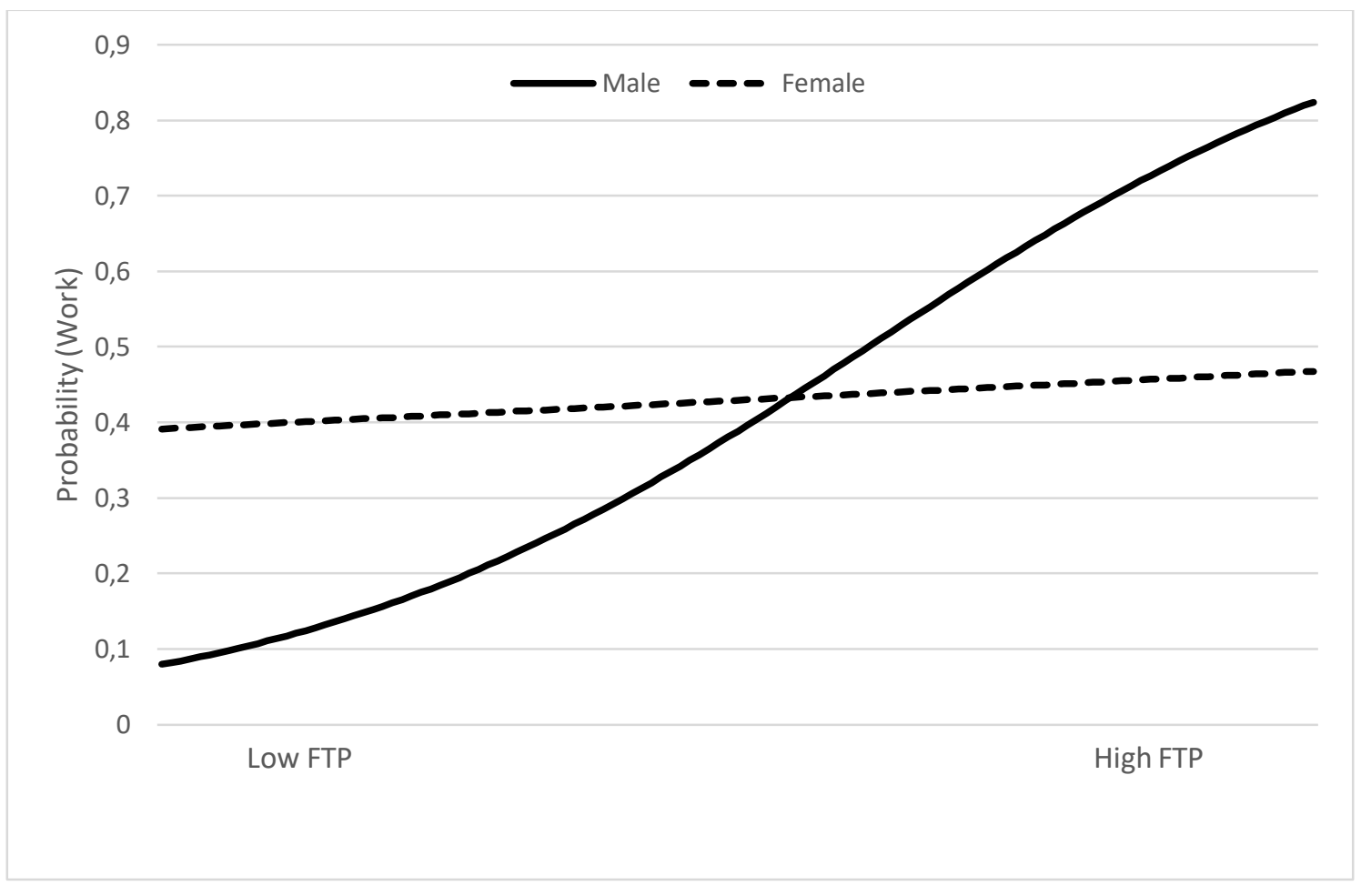

In Model 2, FTP is added to the set of socio-demographic control variables, thus testing the direct effect of FTP on student employment $\left(\mathrm{H}_{1}\right)$. Controlling for other variables, FTP has a positive effect on the likelihood of college student employment. This finding supports hypothesis 1 . In Model 3, the interaction between FTP and gender produced a positive coefficient. To show the moderating effect visually, the scores of FTP were plotted on the $\mathrm{X}$-axis and the respective predicted probabilities of working during college for males and females (using Model 3 ) were plotted on the Y-axis. The interaction between FTP and gender is illustrated in Figure 1. Supporting $\mathrm{H}_{2}$, the relationship between FTP and college employment is stronger for male students compared to female students. 


\section{Discussion}

For many traditional, undergraduate students, working is a fundamental responsibility. Financial considerations play an important role in the decision to work. Students work to pay tuition, fees, living expenses and other costs of attending college. However, some college students use employment as a way to explore career options, gain experience, build a social network, and/or an opportunity to develop professional skills that employers will be expecting upon graduation. This suggests that students are choosing to work with an eye toward the future. As such, the goal of the present study was to examine the extent to which FTP influences the likelihood of working during college. Often it is the case that studies of college student employment focus on the financial determinants of student work or the impact working has on academic outcomes. This study is unique in that it gives attention to the individual characteristics of working students.

In $\mathrm{H}_{1}$, FTP was expected to be directly related to college student employment. The results of logistic regression analysis supported this hypothesis. Students with high FTP were significantly more likely to be working during the survey period. This supports previous studies which have demonstrated that future orientation predicts a variety of lifetime social, economic, and career-oriented behaviors ( Laghi et al., 2013; Golsteyn et al., 2014; Taber \& Blankemeyer, 2015; Laughland-Booÿ et al., 2017). It also suggests that college students view employment while in school as more than just a means for meeting current financial obligation, but as a way to prepare for their occupation after graduation.

In $\mathrm{H}_{2}$, gender was expected to moderate the relationship between FTP and college student employment. This was also supported. Specifically, the results showed that male college students were more likely to show a direct relationship between FTP and employment compared to female students. In other words, compared to female students, future-oriented male students are more likely to work while in college. The results are consistent with existing research which shows gender differences in the degree of strength in a variety of FTP-outcome relationships, such as work, education, and health (Gjesme, 1979; Mello \& Worrell, 2006; Gulley, 2013; Andre et al., 2019).

\subsection{Implications}

Previous research has focused on the adverse effects employment during college may have on grade point average and students' academic progress. Working during college has been portrayed as an unavoidable activity that distracts students from the degree completion and potentially causes them to drop out. However, internships and work experiences during college may help students develop valuable workplace skills that allow them to greater success after graduation. Working during college may also serve as a signal of dependability and self-discipline that enhances employment opportunities later in life.

The present research not only contributes to our understanding of college student employment, but it also has important implications for college administrators, faculty, and counsellors. It appears that students with an orientation toward the future are more motivated to seek employment during college. Internship and work-study coordinators could identify and target these types of students when recruiting quality candidates. However, simply focusing on these types of students is not enough. It is important that a diversity of students become involved in work-related programs. Thus, colleges and universities might consider prompting a greater orientation toward the future in those students who are not so inclined. FTP is malleable and has been demonstrated to be responsive to intervention (Marko \& Savickas, 1998). Experimental research has found that it is possible to influenced people's focus on future events and alter their attitudes about future activities, such as career planning (Liberman \& Trope, 1998; Marko \& Savickas, 1998; Trope \& Liberman, 2000). Writing about the future has been found to elicit a focus on the future and influence people to perform more health-promoting behaviors (Mann, 2001) and have greater interest in volunteerism (Maki, Dwyer, \& Snyder, 2016). A similar method may also spark interest among college students in programs that provide them with work experience. 
In the current study, gender played a significant moderating role in the relationship between FTP and college student employment. The analysis suggests that contemplating the future motivates males to work during college more than females. This finding may reflect the traditional roles of men and women that are associated with Western cultures (Kite et al., 2008). In particular, men are typically focused on goals related to employment and financial security, whereas women are concerned more with goals for marriage and family. The stereotypical views of women as housewives may impact the future career goals of female students causing them to contemplate their future family responsibilities rather than giving attention to professional career exploration (Laughland-Booÿ et al., 2017). The degree to which these gender-based perceptions of future responsibilities impact the employment decisions of college students should be studied further.

The main implication of this research is that educators and college leaders should recognize and appreciate that working college students are not only earning income to meet short term financial needs, but they also perceive employment as a means of improving their long-term future earnings. Many colleges and universities support their students through internship and work-study programs. Research indicates that an internship is the most important credential for recent college graduates to have on their resume (Chronicle of Higher Education \& Marketplace, 2012). Some colleges (e.g., Georgia Tech, Purdue University, and Cornell University) have gone a step further and developed 'co-op' programs in which students alternate full-time employment with semesters in college (Douglas \& Attewell, 2018). Programs like these that view the working lives of students not as a challenge, but as an opportunity for skill acquisition and social networking are consistent with students' goals.

Working while in college is risky. While studies show that working less than 15 hours per week during college is generally helpful to future earnings outcomes, working 15 or more hours a week can have negative effects on students' chances of completing their education (Carnevale \& Smith, 2018). However, some students do not have the option to forgo employment while attending college. Because these students are not receiving enough financial aid and/or financial support from other sources to cover their college expenses, they must work in order to continue in school. It is important for college leaders to inform incoming college freshmen about the risks of working while in school. Colleges and universities also need to address the issue of what type of jobs students hold while in school. Through mentorships, tutoring, and campus programs, students might better understand the kinds of job opportunities that yield the best results and how they can coordinate classroom activities with their current jobs and with their long-term career goals. Moreover, because a significant relationship was found between FTP and college employment, interventions based on time perspective may prove useful in helping college students balance school and work.

\subsection{Limitations and Future Directions}

The results of this investigation contribute to our understanding of the forces that motivate students to work while in college. This is the first study to consider FTP as an important variable that shapes individuals' employment decision while attending college. Despite the strengths of this study, several limitations should be considered. The sample studied was largely White/Caucasian and had parents who were middle or high income. The sample was taken from a 4-year university in the southeastern portion of the United States. Therefore, the findings may not be generalizable. Additionally, this study was based on cross-sectional analysis and self-report data, which are prone to biases including recall and social desirability. The present study is also limited by the fact that only a few socio-demographic variables are included in the analysis as controls and predictors of student employment. Other economic factors, such as living arrangements (Demeulemeester \& Rochat, 2000), financial grants (Broton et al., 2016), and parental/private transfers (Kalenkoski \& Pabilonia, 2010; Bachmann \& Boes, 2014) also influence students' work behavior.

To correct these weaknesses and improve on the current study, future research on a broader demographic sample would be desirable. Future studies could include additional economic, sociodemographic, and psychological predictors in an attempt to determine how these variables impact student employment and how they interact with one another. 
Regarding extensions of the current study, it would be interesting to explore the effect of parental financial preparedness on college student employment. Also, the literature contains a number of piecemeal studies on why students work. The present study suggests that a more holistic approach, integrating the work of economists, psychologists, demographers, educators, and student development specialists, would be beneficial to such an effort. But, these are tasks for the future.

\section{Disclosure Statements}

1. The author of this article confirms that her work complies with the principles of research and publication ethics.

2. No potential conflict of interest was reported by the author.

3. This article was screened for potential plagiarism using a plagiarism screening program.

\section{References}

Aiken, L. S., \& West, S. G. (1991). Multiple regression: Testing and interpreting interactions. Newbury Park, CA: Sage.

Andre, L., Peetsma, T. T. D., van Vianen, A. E. M., Jansen in de Wal, J., Petrović, D. S., \& Bunjevac, T. (2019). Motivated by future and challenges: A cross-cultural study on adolescents' investment in learning and career planning. Journal of Vocational Behavior, 110(A), 168-185.

Avdic, D., \& Gartell, M. (2015). Working while studying? Student aid design and socioeconomic achievement disparities in higher education. Labour Economics, 33, 26-40.

Bachmann, A., \& Boes, S. (2014). Private transfers and college students' decision to work. Economics of Education Review, 42, 34-42.

Bound, J., Lovenheim, M. F., \& Turner, S. (2012). Increasing time to baccalaureate degree in the United States. Education Finance and Policy, 7(4), 375-424.

Broton, K. M., Goldrick-Rab, S., \& Benson, J. (2016). Working for college. Educational Evaluation and Policy Analysis, 38(3), 477-494.

Burks, S. V., Carpenter, J. P., Goette, L., \& Rustichini, A. (2009). Cognitive skills affect economic preferences, strategic behavior, and job attachment. Proceedings of the National Academy of Sciences, 106(19), 7745-7750.

Cadena, B. C., \& Keys, B. J. (2015). Human capital and the lifetime costs of impatience. American Economic Journal: Economic Policy 7(3), 126-153.

Carnevale, A. P., \& Smith, N. (2018). Balancing Work and Learning: Implications for Low-Income Students. Retrieved July 9, 2019 from https://1gyhoq479ufd3yna29x7ubjn-wpengine.netdna-ssl.com/wp-content/uploads/Low-IncomeWorking-Learners-FR.pdf

Chabris, C. F., Laibson, D., Morris, C. L., Schuldt, J. P., Taubinsky, D., Babikov, K., ... Woolley, A. W. (2008). Individual laboratory-measured discount rates predict field behavior. NBER Working Paper Series. Retrieved January 6, 2019 from http://www.nber.org/papers/w14270

Chronicle of Higher Education, \& Marketplace (2012). The role of higher education in career development: Employer perceptions. The Chronicle of Higher Education. Retrieved February 12, 2019 from https://www.chronicle.com/items/biz/pdf/Employers\%20Survey.pdf

Demeulemeester, J. L., \& Rochat, D. (2000). Labour participation of higher education students. Labour, 14(3), 503-522.

Douglas, D., \& Attewell, P. (2018). Assessing the impact of student work during college. Retrieved July 9, 2019 from https://smlr.rutgers.edu/sites/default/files/eerc_working_students_012119.pdf

Duckworth, A. (2018). Grit: The power of passion and perseverance. New York: Scribners.

Dundes, L., \& Marx, J. (2006). Balancing work and academics in college: Why do students working 10 to 19 hours per week excel? Journal of College Student Retention: Research, Theory \& Practice, 8(1), 107-120.

Ferrari, L., Nota, L., \& Soresi, S. (2010). Time perspective and indecision in young and older adolescents. British Journal of Guidance \& Counselling, 38(1), 61-82. 
Fischer, K. (2014). The employment mismatch: A college degree sorts job applicants, but employers wish it meant more. The Chronicle of Higher Education. Retrieved June 29, 2019 from https://www.chronicle.com/article/theemployment-mismatch/

Frederick, S., Loewenstein, G., \& O'donoghue, T. (2014). Time discounting and time preference: A critical review. Journal of Economic Literature, 40(2), 351-401.

Garcia, L. L., Bohlig, M., \& Adkins, C. (2020). The early impacts oc COVID-19 on the community college experience. Retrieved August 11, 2020 from https://diverseeducation.com/article/183750/

Gjesme, T. (1979). Future time orientation as a function of achievement motives, ability, delay of gratification, and sex. Journal of Psychology: Interdisciplinary and Applied, 101, 173-188.

Golsteyn, B. H. H., Grönqvist, H., \& Lindahl, L. (2014). Adolescent time preferences predict lifetime outcomes. The Economic Journal, 124(580), F739-F761.

Greene, B. A., \& DeBacker, T. K. (2004). Gender and orientations toward the future: Links to motivation. Educational Psychology Review, 16(2), 91-120.

Gulley, T. (2013). Time perspective and physical activity among central appalachian adolescents. Journal of School Nursing, 29(2), 123-131.

Hart Research Associates. (2016). Falling short? College learning and career success. In NACTA Journal (Vol. 60). $\begin{array}{llll}\text { Retrieved } & \text { June } & 28, & \text { from }\end{array}$ https://www.aacu.org/sites/default/files/files/LEAP/2015employerstudentsurvey.pdf

Henson, J. M., Carey, M. P., Carey, K. B., \& Maisto, S. A. (2006). Associations among health behaviors and time perspective in young adults: Model testing with boot-strapping replication. Journal of Behavioral Medicine, 29, 127-137.

Hershey, D. A., \& Mowen, J. C. (2000). Psychological determinants of financial preparedness for retirement. The Gerontologist, 40(6), 687-697.

Hobbs, S., Stack, N., McKechnie, J., \& Smillie, L. (2007). Talking about work: School students' views on their paid employment. Children and Society, 21(2), 123-135.

HSBC Holdings, (2018). The value of education- The price of success. Retrieved July 9, 2019 from https://www.us.hsbc.com/value-of-education/

Jacobs-Lawson, J. M., Hershey, D. A., \& Neukam, K. A. (2005). Gender differences in factors that influence time spent planning for retirement. Journal of Women \& Aging, 16(3-4), 55-69.

Janeiro, I. N. (2010). Motivational dynamics in the development of career attitudes among adolescents. Journal of Vocational Behavior, 76(2), 170-177.

Kalenkoski, C. M., \& Pabilonia, S. W. (2010). Parental transfers, student achievement, and the labor supply of college students. Journal of Population Economics, 23(2), 469-496.

Keough, K. A., Zimbardo, P. G., \& Boyd, J. N. (1999). Who's smoking, drinking, and using drugs? Time perspective as a predictor of substance use. Basic and Applied Social Psychology, 21(2), 149-64.

Kite, M. E., Deaux, K., \& Haines, E. L. (2008). Gender stereotypes. In F. L. Paludi \& M. A. Denmark (Eds.), Psychology of women: A handbook of issues and theories (2nd ed., pp. 205-236). Westport, CT: Greenwood Press.

Laghi, F., Baiocco, R., Liga, F., Guarino, A., \& Baumgartner, E. (2013). Identity status differences among Italian adolescents: Associations with time perspective. Children and Youth Services Review, 35(3), 482-487.

Laughland-Booÿ, J., Newcombe, P., \& Skrbiš, Z. (2017). Looking forward: Career identity formation and the temporal orientations of young Australians. Journal of Vocational Behavior, 101, 43-56.

Lennings, C. J. (1994). An investigation of the effects of agency and time perspective variables on career maturity. The Journal of Psychology, 128(3), 243-253.

Liberman, N., \& Trope, Y. (1998). The Role of feasibility and desirability considerations in near and distant future decisions: A test of temporal construal theory. Journal of Personality and Social Psychology, 75(1), 5-18.

Maki, A., Dwyer, P. C., \& Snyder, M. (2016). Time perspective and volunteerism: The importance of focusing on the future. Journal of Social Psychology, 156(3), 334-349.

Mann, T. (2001). Effects of future writing and optimism on health behaviors in HIV-infected women. Annals of Behavioral Medicine, 23, 26-33.

Marko, K. W., \& Savickas, M. L. (1998). Effectiveness of a career time perspective intervention. Journal of Vocational Behavior, 52, 106-119. 
Meier, S., \& Sprenger, C. (2010). Present-biased preferences and credit card borrowing. American Economic Journal: Applied Economics, 2(1), 193-210.

Mello, Z. R., \& Worrell, F. C. (2006). The relationship of time perspective to age, gender, and academic achievement among academically talented adolescents. Journal for the Education of the Gifted, 29(3), 271-289.

Mitola, R., Rinto, E., \& Pattni, E. (2018). Student employment as a high-impact practice in academic libraries: A systematic review. The Journal of Academic Librarianship, 44(3), 352-373.

Neill, C. (2015). Rising student employment: the role of tuition fees. Education Economics, 23(1), 101-121.

San, G. (1986). The early labor force experience of college students and their post-college success. Economics of Education Review, 5(1), 65-76.

Savickas, M. L., Silling, S. M., \& Schwartz, S. (1984). Time perspective in vocational maturity and career decision making. Journal of Vocational Behavior, 25(3), 258-269.

Scott-Clayton, J. (2012). What explains trends in labor supply among U.S. undergraduates? National Tax Journal, 65(1), 181-210.

Sékscińska, K., Rudzinska-Wojciechowska, J., \& Maison, D. A. (2018). Future and present hedonistic time perspectives and the propensity to take investment risks: The interplay between induced and chronic time perspectives. Frontiers in Psychology, 9:920.

Snyder, T. D., de Brey, C., \& Dillow, S. (2019). Digest of Education Statistics, 2017. Retrieved June 28, 2019 from https://nces.ed.gov/pubs2018/2018070.pdf

Stephenson, S. P. (1982). Work in college and subsequent wage rates. Research in Higher Education, 17, $165-178$.

Stern, D., \& Nakata, Y. F. (1991). Paid employment among U.S. college students. The Journal of Higher Education, 62(1), 25-43.

Sutter, M., Kocher, M. G., Glätzle-Rützler, D., \& Trautmann, S. T. (2013). Impatience and uncertainty: Experimental decisions predict adolescents' field behavior. American Economic Review, 103(1), 510-531.

Taber, B. J. (2013). Time perspective and career decision-making difficulties in adults. Journal of Career Assessment, 21(2), 200-209.

Taber, B. J., \& Blankemeyer, M. S. (2015). Time perspective and vocational identity statuses of emerging adults. The Career Development Quarterly, 63(2), 113-125.

Trope, Y., \& Liberman, N. (2000). Temporal construal and time-dependent changes in preference. Journal of Personality and Social Psychology, 79(6), 876-889.

Walpole, M. (2003). Socioeconomic status and college: How SES affects college experiences and outcomes. The Review of Higher Education, 27(1), 45-73.

Zimbardo, P. G., \& Boyd, J. (2008). The time paradox: The new psychology of time that will change your life. New York, NY: The Free Press.

Zimbardo, P. G., \& Boyd, J. N. (1999). Putting time in perspective: A valid, reliable individual-differences metric. Journal of Personality and Social Psychology, 77(6), 1271-1288.

Zimbardo, P. G., Keough, K. A., \& Boyd, J. N. (1997). Present time perspective as a predictor of risky driving. Personality and Individual Differences, 23(6), 1007-1023. 


\section{Appendix}

Table A1. Variable Coding

\begin{tabular}{|c|c|}
\hline & Coding \\
\hline \multicolumn{2}{|l|}{ Dependent Variable: } \\
\hline Employed & $0=$ not working; $1=$ working \\
\hline \multicolumn{2}{|c|}{ Independent Variables: } \\
\hline Gender & $0=$ female $; 1=$ male \\
\hline Age & Measured in years \\
\hline Race & $0=$ white $/$ Caucasian; 1 = all other \\
\hline \multirow[t]{15}{*}{ Parent's Income } & $1=$ Under $\$ 20,000$ \\
\hline & $2=\$ 20,000-\$ 29,999$ \\
\hline & $3=\$ 30,000-\$ 39,999$ \\
\hline & $4=\$ 40,000-\$ 49,999$ \\
\hline & $5=\$ 50,000-\$ 59,000$ \\
\hline & $6=\$ 60,000-\$ 69,000$ \\
\hline & $7=\$ 70,000-\$ 79,999$ \\
\hline & $8=\$ 80,000-\$ 89,999$ \\
\hline & $9=\$ 90,000-\$ 99,999$ \\
\hline & $10=\$ 100,000-\$ 109,000$ \\
\hline & $11=\$ 110,000-\$ 119,000$ \\
\hline & $12=\$ 120,000-\$ 129,000$ \\
\hline & $13=\$ 130,000-\$ 139,000$ \\
\hline & $14=\$ 140,000-\$ 149,000$ \\
\hline & $15=\$ 150,000+$ \\
\hline \multirow[t]{7}{*}{ High School GPA } & $1=$ Less than 2.50 \\
\hline & $2=2.51-2.75$ \\
\hline & $3=2.76-3.00$ \\
\hline & $4=3.01-3.25$ \\
\hline & $5=3.26-3.50$ \\
\hline & $6=3.51-3.75$ \\
\hline & $7=3.76+$ \\
\hline FTP & Measured as sum of scores to Hershey \& Mowen (2000) scale \\
\hline
\end{tabular}


Table A2. Skewness and Kurtosis Statistics for Quantitative Data

\begin{tabular}{lcc}
\hline Predictor (quantitative data) & Skewness & Kurtosis \\
\hline Age (before transformation) & 1.10 & 1.95 \\
Age $^{\mathrm{a}}$ (after transformation) & 0.95 & 1.36 \\
Parent's Income & 0.14 & -1.11 \\
High School GPA (before transformation) & -1.49 & 1.47 \\
High School GPA & -1.06 \\
FTP & -0.59 & -0.74 \\
\hline
\end{tabular}

${ }^{a} \mathrm{~A}$ square root transformation was used to correct for positive skewness in the age variable. bHigh School GPA was reflected and square root transformed. That value was re-reflected to make interpretation easier.

Table A3. Collinearity/Autocorrelation Statistics

\begin{tabular}{cc}
\hline Predictor & Variance Inflation Factor (VIF) \\
\hline Gender & 1.08 \\
Age & 1.08 \\
Race & 1.19 \\
Parent's Income & 1.16 \\
High School GPA & 1.18 \\
FTP & 2.11 \\
FTP×Gender & 2.05 \\
\hline Durbin-Watson & 1.75 \\
\hline
\end{tabular}

